\title{
Health, food and nutrition security and the SDG 2030
}

\author{
A Saúde, a Segurança Alimentar e Nutricional e os ODS 2030
}

\author{
Luiz Eduardo Fonseca \\ Fiocruz Center for Global Health, 4365 - Manguinhos, Avenida Brasil, 4365 - 21040-900 - Rio de Janeiro - Brazil \\ Email:lef@fiocruz.br
}

\begin{abstract}
This article analyses the most recent action plans set out by different agencies and organizations of the United Nations system, including these in as out of the health or nutrition area but that can produce an impact on the health and nutritional status of population and national systems of health care and food production and distribution. It seeks to find common points between these Plans of Action for possible collaboration in a future common agenda between the two areas. In addition, this exercise can also help in the incorporation of new elements and another analysis of variables that influence global policies and national health and food and nutritional security. More than answers, this article seeks to collaborate with some milestones and guidelines to support the governance of the Agenda 2030 and the SDG implementation at a country level. This article obviously does not exhaust the subject, but draws attention to common points that can influence the health and nutrition situation of the national populations. The political dimension and the governance, the coherence and political coordination can contribute to the implementation of the SDG health and FNS and to achieve common objectives, including greater costeffectiveness, because both processes are synergistic.
\end{abstract}

Keywords: health; nutrition; food security; global health; development

\section{Resumo}

Este artigo analisa as mais recentes linhas de ação traçadas por diferentes agências e/ou organizações do sistema ONU, tanto fora quanto dentro dos setores saúde e segurança alimentar e nutricional, que possam produzir impacto sobre a saúde e o estado nutricional das populações e seus sistemas de saúde e de produção e distribuição de alimentos. Com isto pretende-se buscar pontos comuns dessas linhas de ação para possível colaboração numa futura agenda comum entre as duas áreas. Por outro lado, esse exercício pode também ajudar na incorporação de novos elementos outras análises de variáveis que influenciam políticas globais e nacionais de saúde e de segurança alimentar e nutricional. Mais que respostas, este artigo procura colaborar com algumas questões orientadoras para apoiar a governança da implantação da Agenda 2030 e dos ODS em nível dos países. Obviamente não esgota o tema, mas chama a atenção para pontos comuns que podem influenciar a situação de saúde e nutrição das populações nacionais. A dimensão política e de governança, a coerência e coordenação política podem contribuir para a implementação conjunta dos ODS saúde e SAN, pois os dois processos são sinérgicos, e assim alcançar objetivos comuns, inclusive com maior custo-efetividade.

Palavras-chave: saúde; nutrição; segurança alimentar; saúde global; desenvolvimento. 
Global health can be considered an area in the field of public health, as both share the principle of social, political, environmental and economic determinants of health and that this is more than the mere absence of disease [1]. In this context, in the international arena, the importance of dialogue and partnership between health and food and nutritional security (FNS) is reinforced as the challenges arising from globalization face a multifaceted and dynamic world, where different societies generate great diversity of norms, values and interests, as well as live together with large inequalities in the distribution of risks and resources to address them [2], requiring articulated intersectional responses.

Regarding the points of connection between the topics of health and food and nutritional security, we still have an inconclusive global agenda. Despite the release of the 2030 Sustainable Development Agenda and the Sustainable Development Goals (SDG) in September 2015 at the United Nations (UN) headquarters in New York [3], the two topic areas still face the establishment of priorities and common indicators ${ }^{1}$. Although one can recognise that the achievement of the objectives of one sector has influence over the targets of other sectors, the develop and implement an intersectional work plan is still a challenge to several governments.

This article seeks to understand the broad lines of action of different agencies and organizations of the UN system, both out and within the health and food and nutritional security sectors, and highlight those which produce important impact on the health and nutritional status of populations as well as the health systems and the food production and distribution system. It is our intent to seek common points for a future and collaborative common agenda between the two areas. Additionally, we think this exercise can also collaborate with the development and analysis of some global policies variables that influence both national health policies and food and nutritional security.

Obviously, this article is not intended to exhaust the subject, but to draw attention to common points and call the attention to readers about the importance of knowing the main global actors, which are capable of influencing the health and nutritional situation of national populations and use that in future analyses, projects, programs or policy decisions.

\footnotetext{
${ }^{1}$ The United Nations Statistical Commission (UNSC) works with national statistical agencies in the development of a framework for indicators such as suggestion for countries in monitoring the implementation of the Agenda for 2030, which should be submitted for approval in March 2016.
}

A saúde global é uma área inerente ao campo da saúde pública à medida que ambas compartem o princípio da determinação social, política, econômica e ambiental da saúde e que esta é mais que a simples ausência de doença[1]. Nesse sentido, reforça-se, a importância do diálogo e da parceria entre a saúde e a segurança alimentar e nutricional (SAN) na cena internacional, uma vez que os desafios provenientes da globalização esbarram num contexto mundial multifacetado e dinâmico, caracterizado por sociedades com grande diversidade de normas, valores e interesses, bem como por grandes desigualdades na distribuição de riscos e dos recursos para enfrentá-los[2], exigindo respostas intersetoriais bem articuladas.

No que tange os pontos de ligação entre os temas da saúde e da segurança alimentar e nutricional, ainda temos uma agenda global inconclusa. Apesar do lançamento da Agenda do Desenvolvimento Sustentável 2030 e dos Objetivos do Desenvolvimento Sustentável (ODS) em setembro de 2015 na sede das Nações Unidas (ONU), em Nova Iorque[3], as duas áreas ainda têm pela frente uma fase para elaboração de prioridades e indicadores comuns ${ }^{1}$. Embora se reconheça que o alcance dos objetivos de um setor tenha influência sobre os objetivos de outros setores, ainda é um desafio para os governos a elaboração e aplicação de planos de trabalho intersetoriais.

Este artigo procura compreender e relacionar as mais recentes linhas de ação traçadas por diferentes agências e/ou organizações do sistema ONU, tanto fora quanto dentro dos setores saúde e segurança alimentar e nutricional, que possam produzir impacto sobre a saúde e o estado nutricional das populações e seus sistemas de saúde e de produção e distribuição de alimentos. Com isto pretende-se buscar pontos comuns dessas linhas de ação para possível colaboração numa futura agenda comum entre as duas áreas. Por outro lado, achamos que esse exercício pode também ajudar na incorporação de novos elementos na análise de algumas políticas globais e às variáveis que influenciam as políticas nacionais de saúde e de segurança alimentar e nutricional. Obviamente não se pretende esgotar o tema, mas chamar a atenção para pontos comuns e sinalizar aos leitores sobre a importância de conhecer o que pregam e pretendem os principais atores globais que podem influenciar a situação de saúde e nutrição das populações nacionais e, quem sabe, poder tirar fruto desta reflexão em futuras análises, projetos, programas ou tomadas de decisão política.

\footnotetext{
${ }^{1}$ A Comissão de Estatísticas das Nações Unidas (UNSC) trabalha junto as agencias de estatísticas nacionais no desenvolvimento de um quadro de indicadores como sugestão para os países no monitoramento da implantação da Agenda 2030, que deverá ser submetido a aprovação em Março de 2016.
} 
The 2030 Sustainable Development Agenda (2030 Agenda) and the Sustainable Development Goals (SDG)

The 2010 UN Summit on the Millennium Development Goals (MDGs) - agreed in 2000 to be achieved in 2015 - has concluded that the adoption of a global plan of eight goals ${ }^{2}$ for the eradication of poverty was very significant to create a compromise of Heads of State from around the world with the health of women and children and against hunger [4]. However, in 2015 not all countries had reached the agreed goals, although the results overall were encouraging: $14 \%$ of the world's population living in extreme poverty compared to $47 \%$ in 1990; the number of undernourished people has dropped to $12.9 \%$ in 2014 as compared to $23.3 \%$ in 1990; access to primary education was $91 \%$ in 2015 against $83 \%$ in 2000 , with attention to the significant increase in the number of literate girls; the mortality of children under five years of age fell from 90 to 43 deaths per 1000 live births and maternal mortality fell $45 \%$ worldwide since 1990; HIV infection also dropped 40\% since 2000, and during 201513.6 million people living with HIV received antiretroviral treatment, in comparison of 800 thousand in 2003; the incidence of malaria fell $37 \%$ from 2000 to 2015 and malarial mortality dropped $58 \%$ in the same period; tuberculosis mortality fell $45 \%$ from 1990 to 2013 ; access to drinking water reached $91 \%$ of the world's population in $2015 ; 2.1$ billion people had access to sanitation and the number using open defecation fell to half; the official development assistance (ODA) increased by $66 \%$ in real terms between 2000 and 2014, reaching 135 billion dollars. In addition, much of the global population had access to the cell phone and the internet [5].

It is undeniable that a global agenda contributes to promote effective global actions; however, large parts of poor and vulnerable populations are still far from the successes achieved. Not only is there occurence of disparities between regions of the globe, but also inside a countries and even within the same regions. In most regions of the globe still persists: 1) inequity (between: genders, rich and poor, rural and urban, among other), 2) malnutrition and hunger, 3) the lack of access to basic health services, as well as education and transportation, 4) environmental degradation and 5) armed conflicts. Those issues still threaten the health and human development.

\footnotetext{
2 The 8 MDGs: 1) eradication of poverty; 2) universal primary education; 3) gender equality; 4) reducing child mortality; 5) improving maternal health; 6) fight against HIV-AIDS, malaria and tuberculosis; 7) environmental sustainability; 8) global partnership for development.
}

\section{A Agenda do Desenvolvimento Sustentável 2030 (Agenda 2030) e os Objetivos do Desenvolvimento Sustentável (ODS)}

A Cimeira da ONU de 2010 sobre os Objetivos de Desenvolvimento do Milênio (ODM) - acordados em 2000 para serem atingidos em 2015 - concluiu que a adoção de um plano global de oito metas ${ }^{2}$ para a erradicação da pobreza fez com que chefes de estado do mundo todo se comprometessem principalmente com a saúde das mulheres e crianças e contra a fome[4]. Entretanto, em 2015, nem todos os países haviam atingido as metas acordadas, embora os resultados alcançados globalmente fossem animadores: $14 \%$ da população mundial vivendo em extrema pobreza em comparação aos $47 \%$ de 1990; o numero de pessoas desnutridas baixou para 12,9\% em 2014 em comparação aos 23,3\% de 1990; o acesso à educação primária foi de $91 \%$ em 2015 contra $83 \%$ em 2000, com atenção ao incremento expressivo do numero de meninas alfabetizadas; a mortalidade de menores de 5 anos caiu de 90 para 43 mortes por 1.000 nascimentos vivos e a mortalidade materna caiu $45 \%$ em todo o mundo desde 1990; a infecção pelo HIV também caiu 40\% desde 2000 e em 2015 13,6 milhões de pessoas vivendo com o HIV recebiam tratamento antirretroviral, em comparação dos 800 mil em 2003; de 2000 a 2015 , a incidência de malária caiu $37 \%$ e a mortalidade por malária 58\%; de 1990 a 2013, a mortalidade por tuberculose caiu 45\%; em 2015, o acesso à água potável foi de $91 \%$ da população mundial; 2,1 bilhão de pessoas receberam acesso ao saneamento e com isso caiu a metade o numero de defecações ao ar livre; a ajuda oficial ao desenvolvimento aumentou $66 \% \mathrm{em}$ termos reais entre 2000 e 2014, alcançando 135 bilhões de dólares; além disso, grande parte da população global teve acesso ao telefone celular e à internet[5].

É inegável que uma agenda global contribui para promover ações globais eficientes, entretanto imensas populações pobres e vulneráveis ainda se encontram a parte dos sucessos alcançados. A questão que se coloca é que não há somente disparidades entre regiões do planeta, mas também dentro de um mesmo país e até de uma mesma região. Em muitas partes do planeta ainda persiste: 1) a inequidade (entre gêneros, entre pobres e ricos, entre urbano e rural, etc), 2) a subnutrição e a fome, 3) a falta de acesso a serviços básicos de saúde, assim como educação e transporte, 4) a degradação ambiental e 5) os

\footnotetext{
${ }^{2}$ As 8 ODMs: 1) erradicação da pobreza; 2) ensino básico universal; 3) igualdade de gêneros; 4) redução da mortalidade infantil; 5) melhoria da saúde materna; 6) combate ao HIV-AIDS, malária e tuberculose; 7) sustentabilidade ambiental; 8) parceria mundial para o desenvolvimento.
} 
The 2030 Agenda is the new agreement with the Member States of the United Nations as of September 2015, governing the process of global development for the next 15 years and composed of 17 SDG (Table 1) and 169 goals. Among the 17 objectives, two of them (SDG 16 and 17) are related to 'means of implementation' of the ODS; one of them refers to food and nutrition security (SDG 2) and another to health (SDG 3). Both SDGs are referred as: "end hunger, achieve food security and improved nutrition, and promote sustainable agriculture' and 'ensure healthy lives and promote well-being for all in all ages" [6] Maybe it is not a coincidence that both SDG are consecutive in the Agenda, as they have a strong causal relationship.

There are eight goals for the SDG FNS [7], two that refer to hunger and malnutrition and six more directly related to the production and marketing of food. Three of the goals of SDG Health are also referred to three of the SDG agenda goals (reducing child mortality, improving maternal health, combating HIV-AIDS, malaria and tuberculosis) and the other six to: no communicable diseases and promoting mental health and well-being; prevention and treatment of abuse of alcohol and addictive substances; traffic-accidents; sexual and reproductive health; universal health coverage, including access to drugs and vaccines; and environmental health [8]. It is impossible to believe that this set of fragmented goals can, itself, achieve the broad objectives of "end hunger, achieve food security, improve nutrition, and promote sustainable agriculture" and "ensure healthy lives and well-being for all at all ages". The reading of the goals set for the two groups (FNS and Health) shows that most of them refer to the individual health (malnutrition) and biological expression of both health and malnutrition. The importance of the collective dimension of both health and nutrition and the need to confront its social, economic and environmental determinants, through i actions promoting social equity and health, to achieve a Health SDG and SDG FNS as proposed in Agenda 2030, has long been recognized.

The scale 'social determinants of health and FNS' justifies a more detailed examination of the relationship between all SDG and the goals of health and FNS. We can see that many SDG contain goals related to health and FNS, as they point out, among other issues, child development, the issue of gender, access to safe water and sanitation, prevention of natural and violence disasters, air pollution, soil and water and their influence on health and food production. conflitos armados. Questões essas que ainda ameaçam a saúde e o desenvolvimento humano.

AAgenda 2030 é o novo acordo pactuado pelos Estados-membros das Nações Unidas, em setembro de 2015, que rege o processo de desenvolvimento global para os próximos 15 anos e está composta de 17 ODS (Quadro 1) e 169 metas. Entre os 17 objetivos, dois deles (ODS 16 e 17) são referentes aos 'meios de implementação' gerais dos ODS, um deles se refere ao ODS SAN (ODS 2) e outro ao ODS Saúde (ODS 3), enunciados como: "acabar com a fome, alcançar a segurança alimentar, melhorar a nutrição, e promover a agricultura sustentável" e "assegurar vidas saudáveis e promover o bem-estar para todos em todas as idades"[6]. Talvez não seja coincidência que os dois ODS sejam consecutivos na Agenda, uma vez que têm fortes relações causais.

São oito metas para o ODS SAN[7], duas que se referem à fome e a desnutrição e seis mais diretamente relacionadas à produção e comercialização de alimentos. Três das metas do ODS Saúde se referem ainda às três metas da agenda dos ODM (redução da mortalidade infantil; melhoria da saúde materna; combate ao HIV-AIDS, malária e tuberculose) e as outras seis a: doenças não-transmissíveis e promoção da saúde mental e bem-estar; prevenção e tratamento do abuso de substâncias aditivas e álcool; acidentes de trânsito; saúde sexual e reprodutiva; cobertura universal de saúde, incluindo o acesso a medicamentos e vacinas; e saúde ambiental[8]. Impossível admitir que este conjunto de metas fragmentadas possa, per si, realizar os objetivos amplos de 'acabar com a fome, alcançar a segurança alimentar, melhorar a nutrição, e promover a agricultura sustentável' e 'assegurar vidas saudáveis e bem-estar para todos em todas as idades'. A leitura das metas traçadas para os dois objetivos (SAN e Saúde) mostra que a maioria delas refere à saúde individual (desnutrição) e a expressão biológica tanto da saúde quanto da desnutrição. Ora, já há muito tempo se reconhece a importância da dimensão coletiva tanto da saúde quanto da nutrição e a necessidade do enfrentamento dos seus determinantes sociais, econômicos e ambientais por meio de ações intersetoriais promotoras da equidade social e sanitária, para o alcance de um ODS Saúde e um ODS SAN, como os propostos na Agenda 2030.

A dimensão 'determinantes sociais da saúde e da SAN' justifica um exame mais detalhado da relação entre todos os ODS e as metas da saúde e da SAN. Podemos observar que muitos ODS contêm metas relacionadas com saúde e SAN, pois tocam, entre outros assuntos, no desenvolvimento infantil, na questão de gênero, acesso à água de qualidade e saneamento, prevenção de desastres naturais e violência, poluições do ar, do solo e da 
Additionally, the 17 SDG and the 169 goals set out in Agenda 2030 are related to the activities and goals proposed by different agencies of the UN itself, targets outlined on a global plan, but that will likely be adapted to the peculiarities of the countries. Let's examine some strategic plans of some agencies, programs and funds of the United Nations system in order to measure the presence and importance of health and FNS in global governance.

\section{Health and nutrition at the UN agencies, programs and funds}

\section{UNICEF 2014-2017[9]}

The mission of the United Nations Children's Fund (UNICEF) is to promote the rights of all children everywhere. Its programs/projects and partnerships aim at ensuring a healthy childhood from the prenatal period until adolescence. In this regard, UNICEF strongly focuses on the area of mother and child through multisectoral programs like vaccination, nutrition, water, sanitation, education and housing, focusing on children and families more vulnerable and excluded.

To address these challenges, UNICEF's strategic plan focuses on seven goals:

(a) Health: support global efforts to reduce the mortality of children under 5 years old.

(b) HIV and AIDS: prevention and treatment of HIV in women, children and teen pregnancies.

(c) Water, sanitation and hygiene: support for global efforts to eliminate open defecation and increased use of clean water, sanitation and healthy environments and better hygiene practices.

(d) Nutrition: support to global efforts to reduce malnutrition with special focus to dwarfism, through nutritional support and best practices of nutrition and care, improved nutrition for the infant and child; micronutrients; nutrition and HIV; community management of acute malnutrition; nutrition in humanitarian situations.

(e) Education: increase access to quality education for boys and girls through better outcomes on improved, equitable and inclusive education learning.

(f) Children protection: support the prevention of violence, abuse, exploitation and neglect of children through child protection systems.

(g) Social inclusion: support to reduce child poverty água e suas influências sobre a saúde e a produção de alimentos.

Além disso, os 17 ODS e as 169 metas definidas na Agenda 2030 se relacionam também com as atividades e metas propostas por diferentes agencias da própria Organização das Nações Unidas, metas essas traçadas num plano global, mas que provavelmente serão adaptadas às peculiaridades dos países. Vamos então examinar alguns planos estratégicos de algumas agências, programas e fundos do sistema das Nações Unidas de forma a medir a presença e a importância da saúde e da SAN na governança global.

\section{Saúde e SAN nas Agências, Programas e Fundos das Nações Unidas}

\section{UNICEF 2014-2017[9]}

O Fundo das Nações Unidas para a Infância (UNICEF) tem como missão promover os direitos de todas as crianças em todos os lugares. Seus programas e parcerias visam assegurar uma infância saudável do período pré-natal até a adolescência. Nesse sentido, enfoca fortemente a área da mãe e da criança, por meio de programas multi-setoriais como vacinação, nutrição, água, saneamento, educação e moradia, enfatizando crianças e famílias mais vulneráveis e excluídas.

Para enfrentar esses desafios, o Plano Estratégico do UNICEF foca sete objetivos:

(a) Saúde: apoiar os esforços globais para reduzir a mortalidade de menores de 5 anos.

(b) HIV e AIDS: prevenção e tratamento do HIV em mulheres, crianças e adolescentes grávidas.

(c) Água, saneamento e higiene: apoio aos esforços globais para eliminar a defecação a céu aberto e aumento do uso de água potável, saneamento e ambientes saudáveis e melhores práticas de higiene.

(d) Nutrição: apoio aos esforços globais para reduzir a desnutrição com foco especial ao nanismo, por meio do apoio nutricional e melhores práticas de nutrição e cuidados, a partir da alimentação do lactente e da criança; micronutriente; nutrição e HIV; gestão comunitária da subnutrição aguda; nutrição em situações humanitárias. (e) Educação: ampliar o acesso à educação de qualidade para meninos e meninas por meio de resultados de aprendizagem melhorados e educação equitativa e inclusiva.

(f) Proteção às crianças: apoio a prevenção da violência, abuso, exploração e negligencia de crianças por meio de sistemas de proteção à criança.

(g) Inclusão social. Apoio para reduzir a pobreza infantil e 
and discrimination against children through better environmental policies and for children at a disadvantage.

\section{UNITAID 2013-2016[10]}

UNITAID is an initiative engaged in finding new ways to prevent, treat and diagnose HIV/AIDS, tuberculosis and malaria more quickly, more cheaply and more effectively. It was created in 2006 on the initiative of the Governments of Brazil, Chile, France, Norway and United Kingdom to act in the dynamics of markets with a perspective to correct and address the shortcomings of drug markets, introducing new products, new formulations and combinations, generating and sustaining demand and thus also by negotiating the best prices. Today, the UNITAID plays a unique role among global health organizations with differentiated and innovative financing approaches which are based on international rate on products such as airline tickets. This fee on airline tickets is collected with different mechanisms and values in nine countries: Cameroon, Chile, Congo, France, Madagascar, Mali, Mauritius, Niger and Republic of Korea. Between 2011 and 2013 in France alone, it has grossed more than 100 million Euros to UNITAID. Another example is the initiative of Norway in collect part of the $\mathrm{CO} 2$ tax for the UNITAID.

This commitment to financial sustainability has influenced other countries to adopt the same procedure. A particularly innovative factor in this sense is the amount of funds coming from African countries. In this way, even the countries that benefit from the agreements reached by UNITAID also provide additional resources to respond to the HIV/AIDS epidemic, malaria and tuberculosis, contributing not only with UNITAID but also providing resources to their own territories in the long term and in a sustainable way.

Among the UNITAID's actions is worth mentioning the Medicines Patent Pool (MPP) created in 2010 as a result of strategic discussions and based on documents prepared by the UNITAID Board meetings over three years.

The current strategy of UNITAID, which runs to 2016, puts great emphasis on innovation, strategic partnerships and its performance monitoring. The priorities are to improve operations management and resource mobilization as well as to make UNITAID a point of reference for the market. Another goal is also work to improve the regularity and predictability of UNITAID resources by expanding its donor base and, at the same time, securing long-term financing commitments of its current members. discriminação contra as crianças através de melhores políticas ambientais e para crianças em situação de desvantagem.

\section{UNITAID 2013-2016[10]}

A UNITAID é uma iniciativa engajada na procura de novos caminhos na luta para prevenir, tratar e diagnosticar o HIV/AIDS, a tuberculose e a malária de forma rápida, barata e mais efetiva. Foi criada em 2006 por iniciativa dos governos do Brasil, Chile, França, Noruega e Reino Unido para atuar na dinâmica mercadológica com a perspectiva de corrigir e combater as deficiências dos mercados de medicamentos, introduzindo novos produtos e novas formulações e combinações, gerando e sustentando demandas e assim também negociando melhores preços. Hoje, o UNITAID desempenha e ocupa um papel singular entre as organizações de saúde global com uma abordagem de financiamento diferenciado e inovador com base na taxa internacional sobre as passagens aéreas (imposição bilhete). Esta taxa é recolhida com valores e mecanismos diferentes em nove países: Camarões, Chile, Congo, França, Madagascar, Mali, Ilhas Maurício, Níger e República da Coreia. Somente na França, esta taxa sobre as passagens aéreas arrecadou entre 2011 e 2013 mais de 100 milhões de Euros para o UNITAID . A Noruega destina parte do imposto sobre as emissões de $\mathrm{CO} 2$ para esta iniciativa.

Este compromisso com a sustentabilidade financeira tem influenciado outros países a adotarem o mesmo procedimento sendo um fator particularmente inovador, o aporte de fundos provenientes de países africanos. Desta forma, mesmo os países que se beneficiam dos acordos realizados através da UNITAID, também disponibilizam recursos adicionais para responder à epidemia de HIV/Aids, malária e tuberculose, contribuindo não só com o UNITAID como também disponibilizando recursos em seus próprios territórios, a longo prazo e de forma sustentável .

Cabe destacar que entre as ações do UNITAID está a constituição do Pool de Patentes para Medicamentos (MPP) criada em 2010, como resultado de discussões estratégicas e documentos elaborados em reuniões do Conselho do UNITAID ao longo de três anos.

A estratégia atual da UNITAID, que vai até 2016, coloca grande ênfase na inovação, parcerias estratégicas e medição de seu desempenho. As prioridades são para melhorar a gestão de operações, a mobilização de recursos e fazer com que o UNITAID seja um ponto de referência para o mercado. E também trabalhar para melhorar a regularidade e a previsibilidade de seus recursos ampliando sua base de doadores e ao mesmo 


\section{UNDP 2014-17[11]}

The United Nations Development Program (UNDP) leads the global development network of the United Nations, acting in more than 170 countries and territories, helping to eradicate poverty and reduce inequalities and exclusion. UNDP cooperates firmly with Governments in their efforts to create goals and priorities and finding solutions that will contribute to global and national development. In each national office of UNDP Representation, the Coordinator shall exercise the functions of resident United Nations coordinator in the country. Through this coordination, UNDP seeks to ensure interagency coordination and more effective use of the $\mathrm{UN}$ resources and international aid.

UNDP acts in five priority areas of action: 1) governance, 2) poverty reduction, 3) crisis prevention and recovery, 4) energy and environment and 5) HIV/AIDS. The UNDP strategic plan for 2014-17 aims to help countries to achieve simultaneously: poverty eradication and significant reduction of inequity and exclusion [12]. This challenge requires the UNDP to rethink the concept of development in the direction of a human and sustainable approach, which means "a process of expansion of the individual choices by expanding their capabilities and opportunities in a sustainable manner from an economic, social and environmental point of view, that can benefit present without compromising the future"[13].

The UNDP strategic plan 2014-17 also focuses on the issue of gender equality and empowerment of women based on a process which includes participatory policies to give voice to the people, advocating South-South and triangular cooperation between countries, as well as advocating the universality of development programs. To carry out its strategic plan, UNDP will focus on:

1. Adoption of paths to sustainable development by supporting:

a) advocacy and leadership in the global development agenda implementation;

b) national development plans and policy reforms;

c) sub-national and local agendas;

d) effective maintenance and protection of natural capital;

e) sustainable access to improved and effective modes of energy generation.

2. Building and strengthening effective democratic governance, supporting:

a) comprehensive responses among actors of the social and economic process to wide and advance sharing on the national targets; tempo, protegendo compromissos de financiamento de longo prazo de seus atuais membros.

\section{PNUD 2014-17[11]}

O Programa de das Nações Unidas para o Desenvolvimento (PNUD) lidera a rede de desenvolvimento global da ONU, atuando em mais de 170 países e territórios, contribuindo para erradicar a pobreza e reduzir as desigualdades e a exclusão. Coopera firmemente com os governos em seus esforços para criar metas e prioridades e encontrar soluções que contribuam para o desenvolvimento global e nacional. Em cada Escritório de Representação nacional, o Coordenador do PNUD exerce as funções de Coordenador residente das Nações Unidas no país. Através desta coordenação, o PNUD procura assegurar a coordenação interagências e o uso mais eficaz dos recursos da ONU e da ajuda internacional.

O PNUD atua em cinco áreas de ação prioritárias: governança, redução da pobreza, prevenção e recuperação da crise, meio ambiente e energia e HIV/AIDS. O Plano Estratégico do PNUD para 2014-17 tem como meta "ajudar os países a alcançar simultaneamente a erradicação da pobreza e uma significante redução das inequidades e da exclusão"[12]. Este desafio leva o PNUD a repensar o conceito de desenvolvimento no sentido de um enfoque humano e sustentável, o que significa, como menciona o documento da Rio +20 , " $u m$ processo de ampliação das escolhas individuais expandindo suas capacidades e oportunidades de maneira sustentável do ponto de vista econômico, social e ambiental, que possa trazer beneficios presentes sem comprometer o futuro"[13]. Para o desenvolvimento de seu Plano Estratégico 201417, o PNUD foca na questão da equidade de gêneros e no empoderamento da mulher, num processo de políticas participativas que dê voz às pessoas, advogando a cooperação sul-sul e triangular entre os países, assim como na universalidade dos programas de desenvolvimento. Para levar a cabo seu PE, o PNUD vai trabalhar com foco em:

1. Adoção de caminhos que levam ao desenvolvimento sustentável, apoiando:

a) defesa e lideranças na implementação da agenda global de desenvolvimento;

b) planos de desenvolvimento nacionais e reformas políticas nos países;

c) agendas subnacionais e locais;

d) efetiva manutenção e proteção do capital natural; 
b) policies and capabilities that seek to improve transparency and accountability;

c) the integrity of public institutions;

d) compliance to laws and safety of citizens;

e) well-being of citizens which depends on improving access to natural resources essential to work and livelihoods.

3. Building resilience by supporting:

a) peace-building and post-conflict situations on transition States;

b) preparation, response and recovery in disaster risk reduction.

The UNDP acknowledges that the objectives proposed in its strategic plan can not be achieved by works alone. Partnerships and coordination of efforts is essential. Accordingly, it is proposed: 1 . to broaden the engagement of UNDP in South-South and triangular cooperation; 2. deepen the partnership with emerging partners, sharing development priorities; 3. place UNDP in a changing world, reflecting the values and norms of the United Nations, but responding effectively the demands of countries.

\section{UNESCO 2014-2021[14]}

The United Nations Educational, Scientific and Cultural Organization (UNESCO) is an agency that promotes cooperation in the fields of education, science, culture, communication and information, which are strategic areas in a new digital era when society in different countries faces pressure and challenge for change. Under this perspective, UNESCO has outlined its strategic plan 2014-2021 which seeks to contribute to peacebuilding, poverty eradication, and sustainable development based on intercultural dialogue. To contribute to those objectives, UNESCO has raised some priorities: gender equality, youth, Africa, least developed countries and countries in transition.

Amongst those strategic objectives, several of them, though indirectly, are related to the health and nutritional sectors SAN. They are: 1) support Member States in developing educational systems that promote lifelong learning for all, inclusive and with quality; 2) support e) acesso sustentável a modos melhorados e efetivos de geração de energia.

2. Construção e reforço de governanças democráticas efetivas, apoiando:

a) respostas contextualizadas entre atores do processo social e econômico que avance em partilhar as metas nacionais;

b) políticas e capacidades que busquem melhorar a transparência e responsabilização (accountability);

c) a integridade das instituições públicas;

d) a obediência das leis e da segurança dos cidadãos;

e) o bem estar dos cidadãos, que depende da melhoria do acesso aos recursos naturais essenciais para o trabalho e os meios de subsistência.

3. Construir resiliência, apoiando:

a) a construção da paz e dos Estados em situações pós-conflito e de transição;

b) preparação, resposta e recuperação em redução dos riscos de desastres.

O PNUD sabe que sozinho não poderá nunca alcançar os objetivos propostos em seu PE. Parcerias e coordenação de esforços é essencial. Nesse sentido, propõe: 1. ampliar o engajamento do PNUD na cooperação sul-sul e triangular; 2. aprofundar a parceria com parceiros emergentes, partilhando prioridades na questão do desenvolvimento; 3. posicionar o PNUD num mundo em mudança, refletindo os valores e normas das Nações Unidas, mas respondendo efetivamente as demandas dos países.

\section{UNESCO 2014-2021[14]}

A Organização das Nações Unidas para a Educação, a Ciência e a Cultura (UNESCO) é uma agência que promove a cooperação nos campos da educação, das ciências, da cultura e da comunicação e informação, pilares estratégicos num tempo em que as sociedades em diferentes países passam por pressões de mudanças e novos desafios na era digital. Foi nessa perspectiva que a UNESCO elaborou seu Plano Estratégico 2014-2021, através do qual procura contribuir para a construção da paz, a erradicação da pobreza, e o desenvolvimento sustentável com base no diálogo intercultural, para o qual contribuem algumas prioridades: igualdade de gêneros, juventude, continente africano, países menos desenvolvidos e países em transição.

Dentre os objetivos estratégicos, diversos se relacionam, ainda que indiretamente, com o setor saúde e a SAN. São eles: 1) apoiar os Estados Membros no desenvolvimento de sistemas educativos que promovam 
students to be creative and responsible world citizens; 3) advance the program Education for All (EFA) and set up a future international agenda of education; 4) strengthen policies and science, technology and innovation systems at national, regional and global level; 5) promote international scientific cooperation around the critical issues for sustainable development; 6) support the inclusive social development, foster intercultural dialogue for a culture congregation and promote ethical principles; 7) protect, promote and transmit the world cultural heritage; 8) foster the creativity and diversity of cultural expressions; 9) promote freedom of expression, development of the media and access to information and knowledge.

\section{UNEP 2014-2017[15]}

The United Nations Environment Program (UNEP) has been, since 1972, the voice of the United Nations to promote the care and the judicious use of the environment for sustainable development. Its strategic plan 2014-2017 is therefore directly linked to these commitments. It must not be forgotten that the Declaration of Rio +20 assumes that health is cause and effect of sustainable development on the environment.

In this regard, UNEP works with seven priority areas: 1) climate change and renewable energy; 2) disasters and conflicts focusing on the reduction of environmental degradation; 3) management of ecosystems and biodiversity through management of land, living beings and water resources management,; 4) environmental governance; 5) control of harmful substances and waste that cause impacts on the environment and human health; 6) sustainable efficiency in the exploitation and consumption of natural resources; 7) research, scientific information and knowledge to support policy makers in environmental management.

In its strategic plan, UNEP assumes that environmental issues relate directly to food production and food and nutrition security, also to the consequences of climate change in the appearance of emerging diseases and the challenges of the human adaptation to new natural scenarios, especially those linked to lack and to the use of water, the use of toxic substances in nature and food production and their consequences for human health. uma aprendizagem ao longo de toda a vida para todos, de qualidade e inclusivo; 2) apoiar os estudantes para que sejam cidadãos mundiais criativos e responsáveis; 3) fazer progredir o programa Educação para Todos (EPT) e configurar uma futura agenda internacional da educação; 4) fortalecer os sistemas e as políticas de ciência, tecnologia e inovação nos planos nacional, regional e mundial; 5) promover a cooperação científica internacional em torno dos problemas críticos para o desenvolvimento sustentável; 6) apoiar o desenvolvimento social inclusivo, fomentar o diálogo intercultural para um encontro entre culturas e promover princípios éticos; 7) proteger, promover e transmitir o patrimônio cultural mundial; 8) fomentar a criatividade e a diversidade das expressões culturais; 9) promover a liberdade de expressão, o desenvolvimento dos meios de comunicação e o acesso à informação e ao conhecimento.

\section{PNUMA/UNEP 2014_2017[15]}

O Programa das Nações Unidas para o Meio Ambiente (PNUMA) tem sido, desde 1972, a voz das Nações Unidas para a promoção do cuidado e do uso sensato do meio ambiente em prol do seu desenvolvimento sustentável. Seu Plano Estratégico 2014-2017 está, portanto, diretamente vinculado a esses compromissos. Não se pode esquecer que a Declaração da Rio+20 assume que a saúde é causa e efeito do desenvolvimento sustentável do meio ambiente.

Nesse sentido, o PNUMA trabalha com 7 áreas prioritárias: 1) mudança climática e uso de energia renovável; 2) desastres e conflitos focando a redução da degradação ambiental; 3 ) manejo de ecossistemas e da biodiversidade através da gestão da terra, dos seres vivos e dos recursos hídricos; 4) governança ambiental; 5) controle de substâncias nocivas e resíduos que causem impactos no ambiente e na saúde humana; 6) eficiência sustentável no exploração e consumo dos recursos naturais; 7) pesquisa, informação científica e conhecimentos para subsidiar formuladores de políticas no manejo ambiental.

Em seu Plano Estratégico o PNUMA assume que as questões do meio ambiente se relacionam diretamente à produção de alimentos e à segurança alimentar e nutricional, às consequências de uma mudança climática no aparecimento de enfermidades emergentes e nos desafios da adaptação humana a novos cenários naturais, principalmente aos ligados a falta e ao uso da água, do uso de substâncias toxicas na natureza e produção de alimentos e sua consequência para a saúde humana. 


\section{UNPF 2014-17[16]}

The United Nations Population Fund (UNPF) is the UN agency that deals with population issues, and is responsible for the expansion of the possibilities for women and young people in having a healthy sexual and reproductive life. To this end, UNPF, from an analytical and consultative process, outlined a Strategic Plan 2014-17 which calls for universal access to health services and a healthy diet, focusing on the reduction of maternal mortality from the reproductive health and family planning. For UNPF, reducing the complications of pregnancy and childbirth and decreasing orphanhood, maternal mortality, neonatal mortality and size of families can bring significant benefits to the family economy, contributing to reduce poverty, improve access to education, especially of girls, help on equity between genders, ensuring an important steps on the path to a sustainable development. UNPF also makes effort for expanding partnership with governments and other UN agencies to strengthen the effectiveness of all UN and governmental programs.

The UNPF Strategic Plan 2014-2017 provides initiatives and products needed to achieve their objectives and goals: 1) increased availability and use of integrated sexual and reproductive health that take into account gender issues; 2) priority to adolescents, especially the younger ones, in national development policies and programs, greater availability of sex education and sexual and reproductive health services; 3 ) greater equality between genders, more empowerment of women and girls and expansion of reproductive rights for women, adolescents and young people marginalized and vulnerable; 4) strengthening national policies and international development programs through the integration of empirical analysis based on demographic dynamics and their relationship with sustainable development, sexual and reproductive health, reproductive rights, the fight against HIV and gender equality.

\section{WHO 2014-2019[17]}

In 2012, the World Health Organization (WHO) Member States agreed to the criteria for health priorities during the period from 2014 to 2019, which is covered by the $12^{\text {th }}$ WHO General Work Plan. Among those priorities we can highlight: 1) current demographic and epidemiological trends with regard to urgent, emerging and neglected health issues, according to the burden of disease in global, regional and national levels; 2) specific needs of countries to WHO (through coop-

\section{UNFPA 2014-17[16]}

O Fundo de População das Nações Unidas - FNUAP é a agência da ONU que trata de questões populacionais, sendo responsável por ampliar as possibilidades de mulheres e jovens levar uma vida sexual e reprodutiva saudável. Para isso, o FNUAP, a partir de um processo analítico e consultivo, traçou um Plano Estratégico 2014-17 que preconiza o acesso universal aos serviços de saúde e à uma alimentação saudável, focando a redução da mortalidade materna a partir da saúde reprodutiva e do planejamento familiar.

Para o FNUAP, reduzir as complicações da gravidez e do parto, diminuir a orfandade, a mortalidade materna, a mortalidade neonatal e o tamanho das famílias podem trazer benefícios significativos à economia familiar, contribuindo para diminuir a pobreza, facilitar o acesso à educação, principalmente das meninas, ajudar na equidade entre os gêneros, assegurando um importante passo no caminho do desenvolvimento sustentável e ampliando a parceria com governos e outras agências da ONU para reforçar a efetividade dos programas de todos.

O Plano Estratégico 2014-2017 do FNUAP prevê resultados e produtos necessários para alcançar seus objetivos e metas: 1) aumento da disponibilidade e uso de serviços integrados de saúde sexual e reprodutiva que levem em conta as questões de gênero; 2) prioridade aos adolescentes, especialmente às mais jovens, nas políticas e programas nacionais de desenvolvimento, maior disponibilidade de educação sexual e serviços de saúde sexual e reprodutiva; 3) maior igualdade entre os gêneros, mais empoderamento das mulheres e das meninas e ampliação dos direitos reprodutivos à mulheres, adolescentes e jovens marginalizados e vulneráveis; 4) fortalecimento das políticas nacionais e programas internacionais de desenvolvimento mediante a integração da análise com base empírica sobre as dinâmicas demográficas e sua relação com o desenvolvimento sustentável, a saúde sexual e reprodutiva, os direitos reprodutivos, a luta contra o HIV e a igualdade entre os gêneros.

\section{OMS 2014-2019[17]}

Em 2012, foi acordado entre os Estados Membros da Organização Mundial da Saúde (OMS) alguns critérios de prioridade para o período de 2014 a 2019, cobertos pelo $12^{\circ}$ Plano Geral de Trabalho da organização. Dentre eles, destacam-se: 1) tendências demográficas e epidemiológicas atuais tendo em conta questões de saúde urgentes, emergentes e negligenciadas, de acordo com a carga de doenças em níveis globais, regionais e nacio- 
eration strategies) should take into account health and development issues within national development plans; 3 ) international agreements that involve or impact the population health (declarations, agreements, resolutions, decisions, documents); 4) the existence of health interventions more financially effective and based on evidence using knowledge, science and technology to improve the health of populations, such as capacitybuilding to respond to global changes and to improve the performance and the intersectoral responses with significant health impacts.

In this regard, WHO is organized in a few categories: one is related to the corporate services of the organization and five of them are more program related. Those programs are: 1) communicable diseases, aiming at the reduction of the burden of these diseases, with emphasis on AIDS, malaria, tuberculosis and neglected tropical diseases; 2) non communicable or chronic disease, aiming to reduce the burden of these diseases including cardiovascular disease, cancer, lung disease, diabetes and mental disorders, as well as deficiencies and injuries through the promotion, risk reduction, prevention, treatment and monitoring of their risk factors; 3) health promotion in all ages, in order to reduce morbidity and mortality and improving the quality of life from pregnancy until old age, taking into account the determinants of health and sustainable development; 4) health systems, to support the strengthening of health systems and their financing with a focus on integration of services to achieve universal coverage, supporting human resources and health information systems, through the transfer of sustainable technologies and quality, promoting research in health systems; 5) preparation, surveillance and response, aimed at rapid interventions in epidemic outbreaks and emergency situations for both the humanitarian aspect and health security.

\section{FAO 2014-17 (Mid-Term Review)[18]}

The United Nations Food and Agriculture Organization (FAO) acts against hunger and malnutrition, advocates safe, adequate, sufficient and nutritious food, which can satisfy the daily needs and cultural preferences of the population, as well as an agriculture that takes into account the management and sustainable use of natural resources, including soil, water, air, the climate and the genetic resources to improve the quality of life for all, especially the poor, in an economically, socially and nais; 2) necessidades específicas dos países em relação a OMS através de estratégias de cooperação que levem em conta os planos de desenvolvimento nacionais de saúde e de desenvolvimento; 3) instrumentos acordados internacionalmente e que envolvem ou impactam a saúde (declarações, acordos, resoluções, decisões, documentos); 4) a existência de intervenções efetivas financeiramente e baseadas em evidências que utilizem o conhecimento, a ciência e a tecnologia para melhorar a saúde das populações, tais como a construção de capacidades para responder às mudanças globais e que melhorem a atuação e as respostas intersetoriais com significantes impactos na saúde.

Para isso a OMS se organiza em algumas categorias: uma delas se relaciona aos serviços corporativos da organização e cinco delas são programáticas. Seus programas são: 1) doenças comunicáveis, visando a redução da carga dessas doenças, com ênfase em AIDS, malária, tuberculose e doenças tropicais negligenciadas; 2) doenças não comunicáveis ou crônicas, visando reduzir a carga dessas doenças que incluem as cardiovasculares, câncer, doenças pulmonares, diabetes e desordens mentais, assim como deficiências e ferimentos, através da promoção, redução de riscos, prevenção, tratamento e monitoramento dos seus fatores de risco; 3) promoção da saúde em todas as idades, visando reduzir a morbidade e mortalidade e melhorando a qualidade de vida desde a gravidez até a velhice, levando em conta os determinantes da saúde e o desenvolvimento sustentável; 4) sistemas de saúde, visando apoiar o reforço dos sistemas de saúde e seu financiamento com foco na integração de serviços para alcançar a cobertura universal, apoiando os recursos humanos e os sistemas de informação em saúde, através da transferência de tecnologias sustentáveis e de qualidade, promovendo a pesquisa nos sistemas de saúde; 5) preparação, vigilância e resposta, visando rápidas intervenções em focos epidêmicos e situações de emergência que visem tanto o aspecto humanitário quanto a segurança em saúde.

\section{FAO 2014-17 (Mid-Term Review)[18]}

A Organização das Nações Unidas para a Alimentação e a Agricultura (FAO) atua contra a fome e a má nutrição, defendendo uma alimentação segura, suficiente e nutritiva, que satisfaça as necessidades diárias e as preferências culturais das populações, e uma agricultura que leve em conta a gestão e utilização sustentável dos recursos naturais, o que inclui o solo, a água, o ar, o clima e os recursos genéticos para contribuir para melhorar a qualidade de vida de todos, especialmente 
environmentally sustainable way. With these measures, FAO believes is contributing to the elimination of poverty as to the economic and social progress of all.

The FAO Strategic Plan for 2014-17 establishes strategic objectives to support expected and reachable results by its Member States in accordance with the institution's strategic framework. For the fulfilment of the goals corresponding to its seven essential functions, the FAO has outlined seven strategic objectives:1) contribute to the eradication of hunger, food insecurity and malnutrition; 2) increase and improve in a sustainable way, the provision of goods and services for agriculture, forestry and fishing activities; 3 ) reduce rural poverty; 4) enable agricultural and food systems more inclusive and efficient; 5) increase the resilience of livelihoods in face of threats and crises; 6) provide knowledge and technical services; 7) transversal objectives (intersectoral): acting in the fields of gender, governance and nutrition/health.

The core functions are: 1) facilitate and support developing countries with regulatory instruments, international agreements, codes of conduct to establish technical standards of production and quality of food; 2) assemble, analyze, monitor and improve database and information in the areas of food, nutrition and agriculture; 3 ) facilitate, promote and support the political dialogue these issues on global, regional and national levels; 4) assist to support the development of national and regional capabilities --to prepare, implement, monitor and evaluate policies, investments and programs based on evidence; 5) advise the support activities that enable the creation, dissemination and improvement of knowledge capture, technologies and good practices among the areas supported by the FAO; 6) facilitate partnerships focused on food and nutritional security, agriculture and rural development, with both Governments, development agencies, civil society and the private sector; 7) defend and be mass media - national, regional and global - in the areas supported by the FAO in other policies.

\section{WFP 2014-2017[19]}

The World Food Program (WFP) aims to support the fight against world hunger, strengthening local, national and regional plans of food and nutritional security. Its strategic plan to 2014-17 presents guidelines to provide nutritious food and enable people, communities and countries to meet their own needs in the field of food and nutrition.

The WFP articulates three strategic lines with different dos pobres, de forma sustentável econômica, social e ambientalmente. Com essas medidas, a FAO acredita estar contribuindo para a eliminação da pobreza e para o progresso econômico e social de todos.

O Plano Estratégico da FAO para 2014-17 estabelece objetivos estratégicos para apoiar resultados esperados e alcançáveis por seus Estados-Membros em conformidade com o marco estratégico da instituição. Para o cumprimento das metas correspondente a sete funções essenciais, a FAO traçou 7 objetivos estratégicos: 1) contribuir para a erradicação da fome, a insegurança alimentar e a desnutrição; 2) aumentar e melhorar, de forma sustentável, a provisão de bens e serviços para a agricultura, as atividades florestais e a pesca; 3) reduzir a pobreza rural; 4) habilitar sistemas agrícolas e alimentares mais inclusivos e eficientes; 5) aumentar a resistência dos meios de subsistência em face a ameaças e crises; 6) prover conhecimentos e serviços técnicos de qualidade; 7) objetivos transversais (intersetoriais): atuação nos campos do gênero, da governança e da nutrição/saúde.

As funções essenciais são: 1) facilitar e apoiar os países em desenvolvimento com instrumentos normativos, acordos internacionais, códigos de conduta, assim o estabelecimento de padrões técnicos de produção e qualidade de alimentos; 2) montar, analisar, monitorar e melhorar a banco de dados e de informações nas áreas da alimentação, nutrição e agricultura; 3) facilitar, promover e apoiar o diálogo político desses assuntos em níveis global, regional e nacional; 4) assessorar a apoiar o desenvolvimento de capacidades - nacional e regional - para preparar, implementar, monitorar e avaliar políticas, investimentos e programas baseados em evidências; 5) assessorar a apoiar atividades que permitam a criação, a disseminação e a melhoria da captação de conhecimento, tecnologias e boas práticas dentre as áreas apoiadas pela $\mathrm{FAO} ; 6$ ) facilitar parcerias voltadas à segurança alimentar e nutricional, à agricultura e ao desenvolvimento rural, tanto com governos, agencias para o desenvolvimento, sociedade civil e o setor privado; 7) defender e ser veículo de comunicação - nacional, regional e global - nas áreas apoiadas pela FAO nas outras políticas.

\section{WFP 2014_2017[19]}

O Programa Alimentar Mundial (World Food Programme - WFP) tem como objetivo apoiar a luta contra a fome no mundo, reforçando os planos locais, nacionais e regionais de segurança alimentar e nutricional. Seu Plano Estratégico para 2014-17 apresenta diretrizes para prover alimentos nutritivos e habilitar pessoas, co- 
goals and objectives. These lines are: 1) respond to the need for sustainable food stocks; 2) restore and rebuild lives and healthy lifestyles; and 3) reduce vulnerabilities and build permanent resistance to them. All these strategic lines have direct cause and effect related to health; some goals as well, such as: a) reducing malnutrition; b) equitable access to healthy foods; c) prevention of situations of food shortage in certain cases such as children, pregnant women and some diseases such as HIV, tuberculosis, malaria and diarrhea; 4) improve access to education and health services to extent the knowledge on food and nutritional security.

\section{Conclusion}

In the current context of globalization, it should be noted to the fact that health and nutritional problems, as well as their determinants, transcend national boundaries (recent epidemics of AIDS, Ebola, SARS, among others; migratory issues; industrialized food products; new agricultural frontiers, among others). The launch of a global agenda for sustainable development until 2030, coordinated by the United Nations and endorsed by most of the head of states of the planet, make us think about the need to strengthen the global governance in the regional fields of health and nutrition, not only for the implementation and development of the goals related to both sectors, but also the goals of other sectors, because this could end up having influence in the development of health and food production systems at country level. In an increasingly interconnected and interdependent world, national Governments are more and more affected in their capacity to protect their populations with respect to the determinants of health and good nutrition.

Other authors (Harvie J. Mikkelsen G, Shak L, 2009) have analyzed the direct relationship of health care and disease with nutritional matters in global panorama and came to the conclusion that "leaders of health care have expressed concern about the need for include the food production system as one of the pillars of individual health, public health and the global health and not just the discussion on basic nutritional factors of food"[20]. The fields of health and nutrition, despite their mutual relation, have developed in separate areas and create separated international instances. However, studying the priority actions of those international agencies, not only in the health and nutrition areas, but also other ar- munidades e países a suprirem suas próprias necessidades em matéria de alimentação e nutrição.

O WFP articula 3 linhas estratégicas com diversos objetivos e metas. Essas linhas são: 1) responder à necessidade de estoques sustentáveis de alimentos; 2) restaurar e reconstruir vidas e modos de vida saudáveis; e 3) reduzir vulnerabilidades nutricionais e construir resistência permanente a elas. Todas essas linhas estratégicas tem relação de causa e efeito diretas com a saúde; algumas metas também, tais como: a) redução da desnutrição; b) acesso equitativo a alimentos saudáveis; c) prevenção de situações de falta de alimentos em determinados casos como crianças, mulheres grávidas e algumas doenças como HIV, tuberculose, malária e diarreia; 4) melhorar o acesso dos serviços de educação e saúde aos conhecimentos de segurança alimentar e nutricional.

\section{Conclusão}

No contexto atual da globalização, deve-se ter em conta que os problemas de saúde e nutrição, assim como seus determinantes, transcendem as fronteiras nacionais (epidemias recentes de SIDA, Ébola, SARS, entre outras; questões migratórias; produtos alimentares industrializados; novas fronteiras agrícolas entre outros). O lançamento de uma agenda global para o desenvolvimento sustentável até 2030, coordenada pelas Nações Unidas e avalizada pela maioria dos chefes de Estado do planeta, nos leva a pensar na necessidade do reforço da governança global e regional nos campos da saúde e da nutrição, não só para implantação e seguimento das metas relativas aos dois setores, mas também das metas dos outros setores porque estas esferas acabam tendo influencia no desenvolvimento dos sistemas de saúde e de produção de alimentos nos países. Num mundo, cada vez mais interconectado e interdependente, governos nacionais são cada vez mais afetados nas suas capacidades de proteger suas populações em relação aos determinantes da saúde e da boa nutrição.

Outros autores tem analisado a relação direta da atenção à saúde e à doença com a questão nutricional (Harvie J, Mikkelsen L, Shak L, 2009) no panorama global e concluído que "lideres da atenção à saúde têm expressado sua preocupação sobre a necessidade de incluir o sistema de produção de alimentos como um dos pilares da saúde individual, da saúde pública e da saúde global e não somente a discussão sobre fatores básicos nutricionais dos alimentos "'[20].

Os campos da saúde e da nutrição, apesar de mutuamente relacionados, se desenvolveram em separado, criando instâncias internacionais distintas. Entretanto, quando se faz um levantamento das ações prioritárias 
eas affected to social and economic development, we can perceive that all of them have, in a certain way, very similar objectives, goals and priorities and all, if not directly, concern the health and nutrition of the population.

Analyzing the SDG3 goals (Health), we realized that the targets for the reduction of deaths of children under than five years old and deaths from chronic diseases (cardiovascular and diabetes, among others) are goals that have strong connection with nutritional matters. In this regard, the WHO programs of chronic diseases and health promotion should seek to broaden the dialogue with the World Food Programme (WFP) which among its three strategic lines, is one to restore and rebuild lives and ways of healthy life. This dialogue should be not only global, but also regional and especially inside the countries where these agencies have their representative offices and, together with national governments, can make consistent efforts for more effective implementation of national development plans and the achievement of its goals on Agenda 2030.

Another relevant note that can be taken from the survey of the strategic action plans of different agencies, programs and United Nations funds, is that health and nutrition appear all the time, even if not directly, as affected areas to the objectives and most of these priorities: UNICEF has clear objectives concerning both health and nutrition, as well as UNITAID and WHO have a direct link with health and FAO and WFP with nutrition, and for UNDP health and nutrition are essential elements for developing nations .

A relevant theme is the possibility in developing joint projects between different areas based on intersectional plans and common programs involving health and food as well as nutritional security. One of the points to be faced in a direct and objective way to achieve this goal is the financing issue. As the document of the Agenda 2030 says, the public funding, both nationally and internationally, will be vital to provide essential public goods and services, as well as will be necessary catalyzing other sources of funding, recognizing the role of the private sector - companies and cooperatives[21]. But, the most important voice for the projects' implementation as for its role as constant observer on the application of transparency throughout the funding process of the initiatives, will be the civil society.

It is clear that achieving the SDG Health and Food Safety and Nutrition goals requires coordinated actions and alignment with compliance with other SDG goals. As the step of the Agenda 2030 and definitions of SDG, along with its goals, have been outlined, its implementation is transferred to the local and national level. This paper presented various actors and global sectoral stra- dessas agencias internacionais não só nas áreas da saúde e da nutrição, mas também de outras áreas afetas ao desenvolvimento social e econômico, percebe-se que todas elas têm, de certa maneira, objetivos, metas e prioridades parecidas e que, se não diretamente, todas se preocupam com a questão da saúde e da nutrição das populações.

Ao analisarmos as metas do ODS3 (Saúde), percebemos que as metas relativas à diminuição de mortes de crianças menores de 5 anos e de mortes por doenças crônicas (cardiovasculares e diabetes, entre outras) são metas que tem forte ligação com a questão nutricional. Nesse sentido, os programas da OMS de doenças crônicas e de promoção da saúde devem procurar ampliar o diálogo com o Programa Alimentar Mundial (WFP) que dentre suas 3 linhas estratégicas uma delas é restaurar e reconstruir vidas e modos de vida saudáveis. Esse diálogo deve ser não somente em nível global, mas também regional e, principalmente, dentro dos países onde estas agências têm seus escritórios de representação e podem, junto com os governos nacionais, coadunar esforços para maior eficácia na implantação dos planos nacionais de desenvolvimento e no alcance das suas metas relativas à Agenda 2030.

Outro dado relevante que se analisa a partir do levantamento dos planos de ação estratégica de diferentes agências, programas e fundos das Nações Unidas é que saúde e nutrição aparecem o tempo todo, mesmo que não diretamente, como áreas afetas aos objetivos e prioridades da maioria delas: o UNICEF tem claros objetivos relativos tanto à saúde quanto a nutrição, assim como a UNITAID e OMS têm ligação direta com a saúde e a FAO e a WFP com a nutrição, para o PNUD saúde e nutrição são elementos essenciais para o desenvolvimento das nações.

Um tema relevante é a possibilidade do desenvolvimento de projetos entre áreas diferentes a partir de planos intersetoriais e programas conjuntos que envolvam a saúde e a segurança alimentar e nutricional. Um dos pontos que deverá ser tratado de forma direta e objetiva para alcançar tal objetivo será a questão do financiamento. Como diz o documento da Agenda 2030, o financiamento público, tanto nacional como internacional, será vital para proporcionar serviços essenciais e bens públicos, assim como será necessário catalisar outras fontes de financiamento, reconhecendo o papel que desempenha o setor privado - empresas e cooperativas[21]. Mas, será a organização da sociedade civil a voz mais importante tanto da implantação desses planos quanto de observador constante de todo o processo de transparências do processo de financiamento das iniciativas.

Fica claro que a realização dos ODS Saúde e Segurança 
tegic plans, which, acting individually, can duplicate actions and waste resources. Therefore, the question of the process of governance arises as a major challenge, at both global and national levels.

More than answers, at this stage in the process, this article seek to raise some key question we believe can assist in guiding future issues related to support the implementation of the Agenda 2030 and the SDG governance at country level:

1. Which instance of Government (commission, working group, etc.) will be responsible for implementing the Agenda 2030 and the SDG in the country?

2. How to access such authority/instance? Health and FNS will have active participation in this governmental instance?

3. How will be the articulation between the Agenda 2030 and the SDG with the preexisting National Development Agendas/Plans?

4. What priority will health and FNS have on the implementation of the Agenda 2030 and the SDG in the countries?

Appropriate and timely responses to these issues, in each country, may contribute to a better implementation of the SDG. In this sense, it will be important to have a political articulation for a joint implementation of both FNS and health SDG. The answer lies in the dimensions of politics and governance. It means that if there is coherence and political coordination, the two processes' implementation results may be synergistic, and the achievement of common goals certainly eased with greater cost-effectiveness. But, along with the political, institutional and managerial arrangements, attention should be given to the development of technical tools and mechanisms capable of ensuring that the politic guiding of coordination will effectively fulfilled. The application of concepts and practices of the strategic-situational planning ${ }^{3}$ applied to the intersectional dimension can be of great value in this occasion.

\section{Conflict of interests}

The authors declare that there are no financial and/or personal relationships that could be viewed as presenting a potential conflict of interests.

\footnotetext{
${ }^{3}$ Strategic planning, widely applied in Latin America, most recently, is a social process intended to draw an articulated set of non-routine actions of a social actor, as institutions and governments, with the possibility to intervene on the reality that, given certain limitations and in the presence of opposition, modify the generator system from a given initial state to a situation purpose of agreement or agreement to a national or institutional design of the political group in the management of that institution or country (Carlos Matus - Policy, planning and government Brasilia, IPEA, 1993)
}

Alimentar e Nutricional necessitam de ações coordenadas e alinhamento com o cumprimento de metas de outros ODS. Realizada a etapa de definições da Agenda 2030 e dos ODS, junto com suas metas, sua implementação se transfere ao nível local e nacional. Este artigo apresentou diversos atores e planos estratégicos setoriais globais, que, agindo isoladamente, podem acabar duplicando ações e desperdiçando recursos. Portanto, a questão da governança do processo se coloca como grande desafio, tanto a nível global quanto nacional.

Mais que respostas, neste momento do processo, este artigo procura colaborar com algumas questões orientadoras para apoiar a governança da implantação da Agenda 2030 e dos ODS em nível dos países:

Que instância de governo (comissão, grupo de trabalho etc.) vai ficar responsável pela implementação da Agenda 2030 e de ODS no país?

Como acessar tal autoridade/instância? Saúde e SAN terão participação ativa nesta instância de condução?

Como se articula a Agenda 2030 e ODS com os Agendas/ Planos Nacionais de Desenvolvimento pré-existentes?

Que prioridade terão a saúde e a SAN na implementação da Agenda 2030 e de ODS nos países?

Respostas adequadas e oportunas a estas questões, em cada país, poderão contribuir para que os ODS sejam melhor implementados. Dai a importância de articular politicamente a implantação conjunta dos ODS saúde e SAN. A resposta se encontra nas dimensões da política e da governança. Isto é, se existir coerência e coordenação política, os dois processos poderão ser sinérgicos e o alcance dos objetivos comuns será certamente facilitado, inclusive com maior custo-efetividade. Mas, junto com os arranjos políticos, institucionais e gerenciais, deve-se dar atenção ainda ao desenvolvimento de instrumentos e mecanismos técnicos capazes de garantir que a orientação política de coordenação se concretize

efetivamente. A aplicação de conceitos e práticas do planejamento estratégico-situacional ${ }^{3}$ aplicado na dimensão intersetorial pode ser de grande valia nesta ocasião.

\section{Conflito de Interesses}

Os autores declaram não existir qualquer relação pessoal ou financeira que possa ser entendida como representando um potencial conflito de interesses.

\footnotetext{
${ }^{3}$ A planificação estratégica, largamente aplicada em países da América Latina, mais recentemente, é um processo social destinado a desenhar um conjunto articulado de ações não rotineiras de um ator social, como instituições e governos, com possibilidade de intervir sobre a realidade para que, dada certas limitações e em presença de oposições, modifique o sistema gerador de uma dada situação inicial para uma situação objetivo de acordo ou em concordância a uma projeto nacional ou institucional do grupo político na gestão daquela instituição ou país (Carlos Matus - Política, planejamento e governo, Brasília, IPEA, 1993)
} 


\section{References/ Referências}

[1] Fried LP, Bentley ME, Buekens P, Burke DS, Frenk JJ, Klag M, Spencer HC. Global health is public health . The Lancet, v 375, Feb 13, 2010

[2] Buss PM, Fonseca LE, Hoirisch C, Ungerer R. - Modulo 4. Desenvolvimento e saúde II: Governanças global e regional e saúde. In: Cooperação para o desenvolvimento em saúde. Editora Fiocruz, Rio de Janeiro, 2016 (no prelo).

[3] United Nations. 2030 Agenda. New York, 2015. Accessible at: https://nacoesunidas. org/pos2015/agenda2030/

[4] United Nations. MDG Summit 2010 Report. New York, 2010. Accessible at: http://www. un.org/en/mdg/summit2010/

[5] United Nations. The MDG Report 2015. New York, 2015. Accessible at: http://mdgs. un.org/unsd/mdg/Resources/Static/Products/ Progress2015/English2015.pdf

[6] United Nations. 2030 Agenda. New York, 2015. Accessible at: https://nacoesunidas. org/pos2015/agenda2030/

[7] United Nations. 17 Objetivos para Mudar o Mundo. New York, 2015. Accessible at: https://nacoesunidas.org/pos2015/

[8] United Nations. 17 Objetivos para Mudar o Mundo. New York, 2015. Accessible at: https://nacoesunidas.org/pos2015/

[9] UNICEF. Strategic Plan 2014-2017. New York, 2013. Accessible at: http://www. unicef.org/strategicplan/files/2013-21UNICEF_Strategic_Plan-ODS-English.pdf

[10] UNITAID. Strategy 2013-2016. Geneva, 2013. Accessible at: http://www.unitaid.eu/ images/strategy/UNITAID-Strategy_20132016-Full-English.pdf
[11]UNDP. Changing the World: Strategic Plan 2014-2017. New York, 2014. Accessible at: http://www.pk.undp.org/content/dam/ undp/library/corporate/UNDP_strategicplan_14-17_v9_web.pdf

[12] UNDP. Changing the World: Strategic Plan 2014-2017. New York, 2014. Accessible at: http://www.pk.undp.org/content/dam/ undp/library/corporate/UNDP_strategicplan_14-17_v9_web.pdf

[13] United Nations. The Future We Want. Rio de Janeiro, 2012. Accessible at: http://www. rio20.gov.br/documentos/documentos-daconferencia/o-futuro-que-queremos/at_ download/the-future-we-want.pdf

[14] UNESCO. Estrategia a Plazo Medio 2014-2021. Paris, 2014. Accessible at: http://unesdoc.unesco.org/ images/0022/002278/227860s.pdf

[15] UNEP. Medium Term Strategy 2014-2017. Nairobi, 2015. Accessible at: http://www. unep.org/pdf/MTS_2014-2017_Final.pdf

[16] UNFPA. Strategic Plan 2014-2017. New York, 2014. Accessible at: https://www. unfpa.org/sites/default/files/resource-pdf/ Strategic\%20Plan,\%202014-2017.pdf

[17] WHO. Not Merely the Absence of Disease. Geneva, 2014. Accessible at: http://apps. who.int/iris/bitstream/10665/112792/1/ GPW_2014-2019_eng.pdf?ua=1

[18] FAO. Plan a plazo medio para 2014-17 (revisado) y Programa de trabajo y presupuesto para 2016-17. Rome, 2015. Accessible at: http://www.fao.org/3/a-mm710s.pdf
[19] WFP. Strategic Plan 2014-2017. Rome, 2014. Accessible at: http://documents.wfp. org/stellent/groups/public/documents/eb/wfpdoc062522.pdf

[20] Harvie J, Mikkelsen L, Shak L - A New Health Care Prevention Agenda: Sustainable Food Procurement and Agricultural Policy - Journal of Hunger \& Environmental Nutrition - Volume 4, Issue 3-4, 2009. Acessível em: http://www.tandfonline.com/doi/ abs/10.1080/19320240903329055

[21] United Nations. 2030 Agenda. New York, 2015. Accessible at: https://nacoesunidas. org/pos2015/agenda2030/ 